\begin{tabular}{l|l|l} 
Jurnal Eksplorasi Akuntansi & e-ISSN : 2656-3649 (Online) \\
Vol. 3, No 3, Agustus 2021, Hal 501-516 & http://jea.ppj.unp.ac.id/index.php/jea/index
\end{tabular}

\title{
Pengaruh Tax Avoidance, Ukuran Perusahaan, dan Dewan Komisaris Independen terhadap Kebijakan Transfer Pricing
}

\author{
Fatimah Sa'diah $^{1 *}$, Mayar Afriyenti ${ }^{2}$ \\ ${ }^{1,2}$ Fakultas Ekonomi, Universitas Negeri Padang \\ *Korespondensi: sadiahfatimah@gmail.com
}

\begin{abstract}
The purpose of this research is to examine the effect of tax avoidance, size of company and independent board of commissioners in the companies that implement policy of transfer pricing. The population of this research are companies engaged in agriculture sector, mining sector and basic and chemical industrial sectors listed on the Indonesia Stock Exchange (IDX) for the 2017-2019 period which total 152 companies. The sampling method was carried out by purposive sampling method, so 85 companies were obtained as research samples. The analytical method used logistic regression analysis. The results of this research indicate that 1) tax avoidance does not effect on transfer pricing 2) the size of company has a positive effect on transfer pricing 3) independent commissioners does not effect on transfer pricing. The contribution of the independent variable in explaining the dependent variable in the amount of $11,5 \%$, while the remaining $88,5 \%$ explained by other variables outside the model.
\end{abstract}

Keywords: company size; independent board of commissioners; tax avoidance; transfer pricing

How to cite (APA $6^{\text {th }}$ style)

Sa'diah, F \& Afriyenti, Mayar. (2021). Pengaruh Tax Avoidance, Ukuran Perusahaan, dan Dewan Komisaris Independen terhadap Kebijakan Transfer Pricing. Jurnal Eksplorasi Akuntansi. 3(3). 501-516.

\section{PENDAHULUAN}

Praktik transfer pricing muncul seiring dengan pesatnya perkembangan teknologi, informasi dan komunikasi yang memudahkan perusahaan-perusahaan multinasional untuk melakukan transaksi antar negara guna mengembangkan bisnisnya. Transfer pricing tercipta karena adanya hubungan istimewa dari pihak-pihak yang berelasi (seperti hubungan antara perusahaan induk dan perusahaan anak) dan muncul untuk tiga tujuan berbeda dari berbagai sisi, yaitu sisi hukum perseroan untuk memperkuat hubungan antara perusahaan dengan pemegang saham, akuntansi manajerial untuk memaksimalkan laba perusahaan dan tujuan perpajakan untuk mengurangi beban pajak perusahaan. Transfer pricing dapat diartikan sebagai harga yang ditetapkan pada saat menjual, membeli maupun mengalihkan sumber daya antar perusahaan yang memiliki hubungan istimewa (Arnold \& Mclntyre, 2002). Transaksi transfer pricing dapat terjadi pada divisi-divisi dalam satu perusahaan, antar perusahaan lokal, atau perusahaan lokal dengan perusahaan yang ada di luar negeri (Hartati, 2014). 
Transfer pricing merupakan suatu bagian terpenting dari perusahaan yang melakukan transaksi barang dan jasa dalam satu grup perusahaan dan antar perusahaan yang memiliki hubungan istimewa. Transfer pricing merupakan sebuah praktik yang wajar digunakan oleh perusahaan yang memiliki hubungan istimewa, salah satu bertujuan untuk memotivasi perusahaan yang memiliki anak perusahaan dengan cara mengalihkan aset serta jasa dalam grup perusahaan. Awalnya pelaksanaan praktik transfer pricing digunakan oleh perusahaan untuk menilai kinerja antar divisi dan cabang perusahaan, namun dewasa ini transfer pricing sering dikonotasikan sebagai suatu yang tidak baik dan bermakna "pejorative", transfer pricing seringkali dilakukan dalam rangka untuk mengurangi total beban pajak dari grup perusahaan multinasional.

Transfer pricing dapat mengakibatkan potensi penerimaan negara berkembang dari sektor pajak berkurang. Sementara, pajak merupakan sumber utama penerimaan negara, bahkan di beberapa negara berkembang pajak menyumbangkan lebih dari $80 \%$ dari total penerimaan negara. Di Indonesia praktik transfer pricing meningkat hingga 20\%. Pada tahun 2016 mantan Direktur P2 Humas DJP Mekar Satria Utama mencatat hampir 2000 perusahaan Penanam Modal Asing (PMA) tidak melakukan pembayaran pajak dengan alasan mengalami kerugian padahal berdasarkan perhitungan yang dilakukan perusahaan tersebut seharusnya membayar rata-rata $\mathrm{Rp} 25$ miliar per tahun dan diketahui skema yang dilakukan merupakan skema transfer pricing (Karunia, 2020). Direktur Eksekutif Center For Indonesian Taxation Yustinus Prastowo (2015) mengatakan, praktik transfer pricing lebih banyak dilakukan perusahaan multinasional dalam meminimalkan pembayaran pajak sehingga mengakibatkan Indonesia berpotensi kehilangan penerimaan pajak hingga Rp100 triliun setiap tahunnya.

Di Indonesia praktik transfer pricing yang pernah diberitakan di media massa diantaranya yaitu praktik transfer pricing yang dilakukan oleh PT Adaro Indonesia. PT Adaro menjual batubara ke perusahaan afiliasinya yang berada di singapura yaitu Coaltrade Services International Pte. Ltd. Harga transfer batubara yang ditetapkan oleh PT Adaro di bawah harga pasar, namun oleh Coaltrade dijual kembali sesuai harga pasar. Praktek transfer pricing ini terungkap karena ada kecurigaan terhadap laporan keuangan Coaltrade pada tahun 2002-2005. Dimana dalam laporan keuangan tersebut, terlihat laba Coaltrade lebih tinggi dari Adaro. Namun pada tahun 2008 kasus ini dihentikan karena tidak ditemukannya bukti (www.ortax.org). Kasus transfer pricing kembali melibatkan Adaro pada tahun 2019 dimana menurut laporan Global Witness: Sejak 2009-2017 Adaro melalui salah satu anak perusahaanya di Singapura, Coaltrade Services International, telah mengatur sedemikian rupa sehingga mereka bisa membayar pajak US\$ 125 juta lebih rendah daripada yang seharusnya dibayarkan di Indonesia (Wareza, 2019).

Penelitian yang dilakukan oleh Arham et al (2020) dan Asyhinta et.al (2019) mengenai transfer pricing di Indonesia dengan objek penelitiannya 41 artikel yang diterbitkan oleh jurnal yang telah terakreditasi SINTA mendapatkan hasil bahwa mayoritas variabel independen yang digunakan pada penelitian transfer pricing di Indonesia yaitu: pajak, tunneling incentive dan mekanisme bonus, namun penelitian ini memilih variabel independennya yaitu: tax avoidance, ukuran perusahaan dan dewan komisaris independen sebagai bagian dari good corporate governance. Peneliti memilih ketiga variabel tersebut karena hasil dari ketiga variabel tersebut masih belum konsisten. Serta penyelidikan yang dilakukan oleh International Monetary Fund (IMF) tahun 2016, Indonesia ditetapkan sebagai peringkat ke sebelas untuk tax avoidance dengan nilai diperkirakan sebesar 6,48 miliar dolar AS yang tidak dibayarkan perusahaan kepada negara (Susilo, 2017).

Tax avoidance adalah penghindaran pajak yang dilakukan secara legal yang tujuan utamanya untuk mema ksimalkan laba perusahaan. Perusahaan multinasional dianggap sering meminimalisasi jumlah pajaknya melalui rekayasa harga yang ditransfer, khususnya pada entitas afiliasi di luar negeri. Rekayasa ini cenderung merelokasi penghasilan secara global 
pada low tax country dan menggeser biaya-biaya dalam jumlah yang lebih besar pada high tax country. Penelitian sebelumnya untuk melihat pengaruh tax avoidance terhadap transfer pricing dilakukan oleh Noviastika F. et al (2016) mendapatkan hasil bahwa pajak berpengaruh signifikan terhadap indikasi melakukan transfer pricing. Hasil berbeda ditemukan oleh Arifin et al (2020) bahwa pajak tidak berpengaruh pada transfer pricing, dan Saputra (2020) menemukan hasil bahwa pajak tidak berpengaruh pada keputusan perusahaan melakukan transfer pricing.

Ukuran perusahaan menjadi sebuah karakteristik perusahaan dalam hubungannya dengan struktur perusahaan. Perusahaan dengan ukuran yang lebih besar memiliki sumber daya dan kesempatan yang lebih banyak untuk melakukan transfer pricing. Perusahaan yang lebih besar cenderung melakukan peningkatan laba termasuk dengan melakukan transfer pricing. Penelitian sebelumnya yang menguji pengaruh ukuran perusahaan terhadap transfer pricing dilakukan oleh Richardson et al (2013) menemukan hasil bahwa ukuran perusahaan secara signifikan terkait positif dengan agresivitas transfer pricing setelah mengendalikan efek sektor industri, hasil yang sama juga ditemukan oleh Pratama (2020) menjadikan ukuran perusahaan sebagai variabel kontrol dan menemukan hasil bahwa ukuran perusahaan secara positif mempengaruhi transfer pricing. Rezky \& Fachrizal (2018) menemukan hasil bahwa ukuran perusahaan berpengaruh terhadap keputusan transfer pricing, Saputra (2020) menemukan hasil bahwa ukuran perusahaan berpengaruh positif terhadap transfer pricing. Sedangkan Hikmatin \& Suryarini (2019) menemukan hasil bahwa ukuran perusahaan tidak mempengaruhi transfer pricing.

Perusahaan yang memiliki sebuah tata kelola yang baik akan mempertimbangkan setiap kegiatan yang dilakukannya termasuk kegiatan transfer pricing. Pada penelitian ini peneliti melihat bagaimana pengaruh dari dewan komisaris independen sebagai bagian dari good corporate governance dalam mempengaruhi kegiatan transfer pricing. Penelitian sebelumnya yang dilakukan oleh Pratama (2020) mendapatkan hasil bahwa corporate governance yang diukur dengan ukuran dewan komisaris dan persentase komisaris independen berpengaruh negatif terhadap transfer pricing. Sedangkan Noviastika F. et al (2016) mendapatkan hasil bahwa good corporate governance menunjukkan pengaruh positif dan tidak signifikan terhadap indikasi melakukan transfer pricing, dimana perusahaan tidak mempertimbangkan tata kelola perusahaan yang baik sebagai dasar penentuan kegiatan transfer pricing. Sedangkan Andayani \& Sulistyawati (2020) mendapatkan hasil good corporate governance memiliki pengaruh positif yang signifikan terhadap transfer pricing.

Maraknya transfer pricing diperkuat dengan pernyataan Direktur Perpajakan Internasional John Hutagaol bahwa kemajuan digital serta globalisasi mengakibatkan semakin meningkatnya volume dan besaran transaksi lintas yurisdiksi baik perdagangan, jasa maupun investasi (Karunia, 2020). Penelitian Fuest et al (2011) mendapatkan bukti yang sejalan dengan anggapan bahwa negara berkembang lebih rentan terhadap strategi peralihan laba multinasional daripada negara maju. Secara empiris terdapat bukti adanya pengaruh dari tax avoidance, ukuran perusahaan dan dewan komisaris independen terhadap transfer pricing. Penelitian ini bertujuan untuk menguji kembali penelitian-penelitian terdahulu karena adanya ketidakkonsistenan hasil dari penelitian sebelumnya serta terdapatnya peningkatan signifikan kasus transfer pricing pada 2018 dibandingkan 2017, dimana Mutual Agreement Procedure (MAP) mencatat jumlah sengketa transfer pricing baru meningkat 20\% (Suwiknyo, 2019).

Oleh karena itu peneliti ingin meneliti kembali mengenai transfer pricing dengan objek penelitiannya perusahaan sektor pertanian, sektor pertambangan dan sektor industri dasar dan kimia yang terdaftar di BEI untuk periode 2017-2019. Sebagian besar investasi sektor pertambangan di negara sumber, seperti Indonesia didominasi oleh modal asing, hal ini menyebabkan sektor mineral dan batubara yang diproduksi berorientasi ekspor ke negara 
asal investor, karena sebagian besar hasil pertambangan merupakan bahan baku industri manufaktur yang membutuhkan pengolahan lebih lanjut (Novriansa, 2019).

Berdasarkan fenomena dan uraian diatas peneliti tertarik untuk menguji kebijakan transfer pricing yang dilakukan oleh perusahaan khususnya perusahaan pada sektor pertanian, sektor pertambangan dan sektor industri dasar dan kimia dengan judul "Pengaruh Tax Avoidance, Ukuran Perusahaan, Dan Dewan Komisaris Independen Terhadap Kebijakan Transfer Pricing."

\section{REVIU LITERATUR DAN HIPOTESIS}

\section{Teori Agensi (Agency Theory)}

Teori agensi menjelaskan perilaku perusahaan dengan berbagai pihak yang dilihat dari perspektif kontrak yang terjadi antara manajemen, pemegang saham/pemilik perusahaan, kreditur, pemerintah dan pihak lainnya yang berkepentingan dalam perusahaan. Teori ini dikembangkan oleh Alchian \& Demsetz (1972) dan Jensen and Meckling (1976).

Agency conflict timbul akibat adanya asimetri informasi antara pemegang saham/pemilik perusahaan dengan manajer perusahaan, dimana manajer berusaha memaksimalkan laba demi kepentingannya dan melakukan segala cara termasuk kebijakan transfer pricing. Pada penelitian ini dari perspektif pajak pemerintah adalah prinsipal dan perusahaan adalah agen. Pemerintah sebagai prinsipal memerintahkan kepada perusahaan untuk melakukan pembayaran pajak sesuai dengan perundang-undangan pajak dan sesuai dengan besaran pajak yang seharusnya dibayar perusahaan kepada pemerintah. Namun hal yang terjadi adalah perusahaan sebagai agen berusaha mengoptimalkan labanya dengan salah satu cara yang dilakukan memperkecil beban pajak yang akan dibayarkan. Penghindaran pajak yang dilakukan oleh perusahaan akan menyebabkan tax ratio sebuah negara menjadi rendah. Menurut Fuest et al (2010) rendahnya tax ratio salah satunya disebabkan oleh profit shifting dengan tujuan penghindaran pajak. OECD pada Action Plan BEPS (Based Erotion Profit Shifting) 2013, menyatakan bahwa skema paling dominan dalam profit shifting yang dilakukan oleh perusahaan multinasional adalah skema transfer pricing.

\section{Transfer Pricing}

Secara umum transfer pricing diartikan sebagai harga yang ditetapkan pada sebuah produk atau jasa yang digunakan saat melakukan transaksi antar divisi atau antar perusahaan yang memiliki hubungan istimewa. Transfer pricing merupakan praktik yang wajar digunakan oleh perusahaan yang mempunyai hubungan istimewa, salah satunya untuk memotivasi perusahaan yang memiliki anak perusahaan dengan cara mengalihkan aset serta jasa dalam grup perusahaan. Namun dewasa ini transfer pricing sering dikonotasikan sebagai suatu yang tidak baik dan bermakna "pejorative", transfer pricing seringkali dilakukan dalam rangka untuk mengurangi total beban pajak dari grup perusahaan multinasional. "pejorative" mengacu pada manipulasi transfer pricing.

Manipulasi transfer pricing dapat didefinisikan sebagai suatu kebijakan atas harga transfer yang berada diatas atau dibawah harga wajar dalam rangka untuk memanfaatkan perbedaan regulasi antar negara, terutama terkait dengan tarif pajak. Dengan demikian, dapat disimpulkan bahwa manipulasi transfer pricing adalah menetapkan harga transfer menjadi "terlalu besar atau terlalu kecil" dengan maksud memperkecil jumlah pajak yang terutang. Terdapat kecenderungan bahwa motif penghindaran pajak lah yang menjadi motivasi utama transfer pricing (Darussalam et al, 2013).

\section{Tax Avoidance}

Tax avoidance diartikan sebagai suatu skema penghindaran pajak dengan cara memanfaatkan celah ketentuan perpajakan tanpa melanggar undang-undang yang telah ditetapkan pada suatu 
negara dengan tujuan meminimalkan beban pajak yang akan dibayarkan. Tax avoidance menjadi sebuah seni dalam melakukan penghindaran pajak tanpa melanggar hukum perpajakan yang berlaku. Tax avoidance merupakan grey area antara tax compliance dan tax evasion, karena tax avoidance akan berdampak pada penerimaan pajak negara, sedangkan pembangunan sebagian besar dibiayai oleh penerimaan pajak negara.

\section{Ukuran Perusahaan}

Ukuran perusahaan adalah suatu skala dimana dapat diklasifikasikan besar kecil perusahaan menurut berbagai cara (total aktiva, log size, nilai pasar saham, dan lain-lain). Pada dasarnya ukuran perusahaan hanya terbagi dalam 3 kategori yaitu perusahaan besar (large firm), perusahaan menengah (medium-size) dan perusahaan kecil (small firm). Penentuan ukuran perusahaan ini didasarkan kepada total asset perusahaan (Machfoedz, 1994). Ukuran perusahaan menurut Undang-Undang No.20 tahun 2008 mengenai usaha kecil, mikro dan menengah, ukuran perusahaan diukur melalui ukuran nilai kekayaan bersih dan hasil penjualannya, perusahaan dibagi menjadi tiga kriteria usaha, yaitu: usaha mikro, usaha kecil dan usaha menengah.

\section{Dewan Komisaris Independen}

Komisaris independen merupakan anggota dewan komisaris yang tidak memiliki hubungan keuangan, hubungan kepengurusan, hubungan kepemilikan saham maupun hubungan lainnya yang dapat mempengaruhi kemampuannya untuk bertindak independen. Menurut UU Nomor 40 Tahun 2007 komisaris independen yang ada dalam pedoman tata kelola perseroan yang baik (code of good corporate governance) adalah "komisaris dari pihak luar". Komisaris independen dapat bertindak sebagai penengah dalam perselisihan yang terjadi diantara para manajer internal dan mengawasi kebijakan manajemen serta memberikan nasihat kepada manajemen (Fama and Jensen 1983).

Dewan komisaris independen memiliki tugas pokok untuk menerapkan good corporate governance pada perusahaan. Seorang komisaris independen berhak menyampaikan pendapat yang berbeda dengan anggota dewan komisaris lain dan pendapatnya dicatat di dalam Berita Acara Rapat Dewan Komisaris dan apabila pendapatnya berbeda secara material maka hal itu wajib dimasukkan ke dalam Laporan Tahunan. Melalui peranan dewan komisaris independen dalam melaksanakan tugas dan fungsinya untuk melakukan pengawasan terhadap operasional perusahaan sehingga dapat memberikan kontribusi dalam pengambilan keputusan termasuk pelaksanaan kebijakan transfer pricing.

\section{Pengaruh Tax Avoidance terhadap Transfer Pricing}

Berdasarkan teori keagenan, terdapat konflik kepentingan antara manajer dan pemegang saham. Manajer sebagai pengelola perusahaan berusaha untuk memberikan kesejahteraan kepada pemegang saham agar mendapatkan kepercayaan dari pemegang saham dengan cara memaksimalkan laba perusahaan, dari perspektif pajak pemerintah adalah prinsipal dan perusahaan adalah agen. Pemerintah sebagai prinsipal memerintahkan kepada perusahaan untuk melakukan pembayaran pajak sesuai dengan perundang-undangan pajak dan sesuai dengan besaran pajak yang seharusnya dibayar perusahaan kepada pemerintah. Namun perusahaan berusaha memperkecil beban pajak yang dibayarkan untuk mengoptimalkan laba perusahaan. Tax avoidance merupakan salah satu prosedur yang dilakukan untuk memperkecil pembayaran pajak yang akan berdampak pada peningkatan laba perusahaan.

Salah satu cara tax avoidance yang dilakukan perusahaan adalah dengan melakukan kebijakan transfer pricing. Hadifadhlulloh (2020) menyatakan bahwa pihak perusahaan akan melakukan berbagai cara untuk menghindari pajak yang tinggi dengan mengalihkan laba ke 
perusahaan yang memiliki tarif pajak yang relatif lebih rendah dengan melakukan mekanisme transfer pricing pada perusahaan yang memiliki hubungan istimewa atau cabang perusahaan yang memiliki intensitas tarif pajak yang relatif lebih rendah. Penelitian yang dilakukan oleh Rosad et al (2020) dan Pamungkas \& Nurcahyo (2018) mendapatkan hasil bahwa tax avoidance mempunyai pengaruh positif signifikan terhadap transfer pricing. Jafri \& Mustikasari (2018) juga mendapatkan hasil bahwa perencanaan pajak berpengaruh terhadap perilaku transfer pricing dan Hasil yang sama juga didapatkan oleh Saraswati \& Sujana (2017) dan Noviastika F. et al (2016) bahwa variabel pajak berpengaruh positif pada indikasi melakukan transfer pricing. Berdasarkan penjelasan diatas maka dirumuskan hipotesis pertama sebagai berikut.

H1: Tax avoidance berpengaruh positif terhadap transfer pricing.

\section{Pengaruh Ukuran Perusahaan terhadap Transfer Pricing}

Perusahaan yang memiliki ukuran lebih besar biasanya memiliki aktivitas yang lebih kompleks dari pada perusahaan yang berukuran kecil. Perusahaan yang berukuran besar juga menyebabkan terjadinya konflik kepentingan yang lebih besar sehingga manajemen sebagai pengelola perusahaan akan berusaha untuk menghasilkan laba yang lebih tinggi dibandingkan dengan perusahaan yang lebih kecil. Semakin besar ukuran perusahaan maka akan semakin banyaknya sumberdaya dan kesempatan perusahaan dalam melakukan praktik transfer pricing. Perusahaan dapat mendirikan anak perusahaan dimana tarif pajak yang dikenakan lebih rendah dari pada negara domisili perusahaan.

Penelitian yang dilakukan Richardson et al (2013) menemukan hasil bahwa ukuran perusahaan secara signifikan terkait positif dengan agresivitas transfer pricing, hasil yang sama juga ditemukan oleh Arifin et al (2020), Pratama (2020), Rezky \& Fachrizal (2018) dan Saputra (2020). Berdasarkan penjelasan tersebut maka dirumuskan hipotesis kedua sebagai berikut:

H2: Ukuran perusahaan berpengaruh positif terhadap transfer pricing.

\section{Pengaruh Dewan Komisaris Independen terhadap Transfer Pricing}

Dewan komisaris independen merupakan bagian dari penerapan good corporate governance. Komisaris independen adalah dewan komisaris yang tidak terafiliasi dengan manajemen, anggota dewan komisaris lainnya , dan pemegang saham pengendali, serta bebas dari hubungan bisnis atau hubungan lain yang dapat mempengaruhi kemampuannya untuk bertindak independen atau semata-mata untuk kepentingan masyarakat (KNKG,2006). Keberadaan komisaris independen dalam perusahaan akan membantu memberikan pengawasan dan pengendalian terhadap aktivitas yang dilakukan oleh perusahaan, sehingga penerapan corporate governance dapat berjalan sesuai dengan peraturan yang berlaku. Dalam teori keagenan, corporate governance muncul karena adanya konflik kepentingan antara pemegang saham dan manajemen serta untuk mengatur tindakan yang akan diambil oleh manajemen termasuk keputusan untuk melakukan transfer pricing. Transfer pricing yang bertujuan baik akan memberikan dampak positif bagi perusahaaan.

Penelitian yang dilakukan oleh Apriyanti et al (2020) mendapatkan hasil bahwa komisaris independen berpengaruh positif signifikan terhadap pengungkapan metode transfer pricing. Berdasarkan hasil penelitian ini, pemerintah, regulator, maupun pemilik perusahaan dapat menggunakan komisaris independen dalam melakukan pengawasan terkait dengan pengungkapan transaksi transfer pricing. Komisaris independen dalam perusahaan dapat membantu memonitor keputusan manajemen dan mendorong manajemen untuk dapat mengungkapkan metode transfer pricing (Lo, 2011). Perusahaan yang memiliki persentase komisaris yang tinggi memiliki pengaruh yang besar dalam melakukan pengungkapan informasi keuangan maupun non keuangan secara lebih rinci atas transaksi yang dilakukan dengan pihak berelasi. Penelitiaan yang dilakukan oleh Rosliani (2018) mendapatkan hasil 
bahwa dewan komisaris independen berpengaruh positif terhadap transfer pricing. Berdasarkan penjelasan tersebut dirumuskan hipotesis ketiga sebagai berikut:

H3: Dewan komisaris independen berpengaruh positif terhadap transfer pricing

\section{METODE PENELITIAN}

\section{Jenis dan Desain Penelitian}

Jenis penelitian ini menggunakan pendekatan kuantitatif. Objek pada penelitian ini yaitu tax avoidance (X1), ukuran perusahaan (X2), dewan komisaris independen (X3) dan transfer pricing (Y). Data penelitian ini bersumber dari laporan keuangan dan laporan tahunan perusahaan sektor pertanian, sektor pertambangan dan sektor industri dasar dan kimia yang terdaftar di bursa efek indonesia (BEI) periode 2017-2019. Data penelitian ini diperoleh dengan cara mengakses website resmi Bursa Efek Indonesia atau Indonesian Stock Exchange (IDX) melalui situs www.idx.co.id. dan melalui website perusahaan yang bersangkutan.

\section{Populasi, Sampel, dan Teknik Pengambilan Sampel}

Populasi pada penelitian ini adalah yang terdaftar di Bursa Efek Indonesia periode 2017-2019. Pada penelitian ini peneliti memilih sektor pertanian, sektor pertambangan dan sektor industri dasar dan kimia yang terdaftar di BEI pada periode 2017-2019 dan menggunakan teknik purposive sampling, dengan berdasarkan kriteria-kriteria yang telah ditentukan.

\section{Tabel 1}

Prosedur Pemilihan Sampel

\begin{tabular}{lc}
\hline \multicolumn{1}{c}{ Kriteria } & Jumlah \\
\hline $\begin{array}{l}\text { Perusahaan sektor pertanian, sektor pertambangan dan sektor industri dasar dan } \\
\text { kimia yang terdaftar di Bursa Efek Indonesia }\end{array}$ & 152 \\
$\begin{array}{l}\text { Perusahaan sektor pertanian, sektor pertambangan dan sektor industri dasar dan } \\
\text { kimia yang tidak melaporkan melaporkan laporan tahunan (Annual Report) atau }\end{array}$ & $(14)$ \\
laporan keuangan secara berturut-turut pada periode 2017-2019 & \\
Perusahaan sektor pertanian, sektor pertambangan dan sektor industri dasar dan & $(53)$ \\
kimia yang mengalami kerugian pada periode 2017-2019 & \\
Perusahaan sektor pertanian, sektor pertambangan dan sektor industri dasar dan \\
kimia yang memiliki informasi yang dibutuhkan peneliti yang berkaitan dengan \\
variabel penelitian
\end{tabular}

\section{Definisi Operasional Variabel \\ Variabel Dependen (Y)}

Transfer pricing merupakan variabel dependen pada penelitian ini yang dilambangkan dengan TP. TP merupakan suatu kebijakan harga yang ditetapkan dalam transaksi antar divisi maupun antar perusahaan yang mempunyai hubungan istimewa. Variabel TP dalam penelitian ini dihitung dengan menggunakan variabel dummy. Perusahaan yang melakukan transaksi penjualan kepada pihak yang memiliki hubungan istimewa, maka diberi nilai 1 (satu). Sedangkan untuk perusahaan yang tidak melakukan transaksi penjualan kepada pihak yang mempunyai hubungan istimewa, maka diberi nilai 0 (nol) (Yuniasih, Rasmini, and $\mathrm{M}$ 2012). 


\section{Variabel Independen (X)}

\section{Tax Avoidance}

Penghindaran pajak (tax avoidance) merupakan tindakan perusahaan untuk memperkecil jumlah pajak yang akan dibayarkan dengan tujuan untuk memperbesar laba perusahaan. Pada penelitian ini tax avoidance diukur dengan menggunakan effective tax rate seperti hal penelitian Dyreng, et al. (2008). Berikut ini adalah rumus ETR:

$$
\mathrm{ETR}=\frac{\text { Beban Pajak }}{\text { Laba Sebelum Pajak }}
$$

\section{Ukuran Perusahaan}

Menurut Riyanto (2013), ukuran perusahaan adalah besar kecilnya perusahaan dilihat melalui besarnya nilai equity, nilai penjualan maupun nilai aset perusahaan. Ukuran perusahaan menggambarkan besar atau kecilnya aset yang dimiliki oleh perusahaan. Ukuran perusahaan dihitung dengan rumus:

$$
\text { Ukuran Perusahaan }(\mathrm{UP})=\operatorname{Ln}(\text { Total Asset })
$$

\section{Dewan Komisaris Independen}

Dewan komisaris independen adalah dewan komisaris yang tidak memihak kepada siapapun baik itu manajemen maupun pemegang saham. Komisaris independen memiliki sekurangkurangnya $30 \%$ dari jumlah seluruh anggota dewan komisaris, sehingga telah memenuhi pedoman good corporate governance guna dalam menjaga independensi (Mauliza, 2013). Proporsi Dewan komisaris independen diukur dengan menggunakan rumus:

$$
\mathrm{DKI}=\frac{j u m l a h \text { dewan } \text { komisaris independen }}{\text { jumlah total dewan } \text { komisaris }}
$$

\section{Metode Pengumpulan Data}

Metode pengumpulan data yang digunakan dalam penelitian ini adalah dengan cara pengumpulan data sekunder yaitu data laporan keuangan sektor pertanian, sektor pertambangan dan sektor industri dasar dan kimia yang di terdaftar di bursa efek indonesia pada periode 2017-2019. Data diperoleh dengan mengakses website resmi BEI www.idx.co.id dan atau mengakses website resmi perusahaan terkait.

\section{Analisis Regresi Logistik}

Model Regresi yang digunakan dalam penelitian ini adalah:

$$
\mathrm{TP}=\alpha+\beta 1 \mathrm{X} 1+\beta 2 \mathrm{X} 2+\beta 3 \mathrm{X} 3+\varepsilon
$$

Keterangan :

$\begin{array}{ll}\text { TP } & : \text { Transfer Pricing, } \\ \alpha & : \text { Konstanta } \\ \mathrm{X} 1 & : \text { Tax Avoidance } \\ \mathrm{X} 2 & : \text { Ukuran Perusahaan } \\ \mathrm{X} 3 & : \text { Dewan Komisaris Independen } \\ \beta 1-\beta 2-\beta 3 & : \text { Koefisien regresi } \\ \varepsilon & : \text { Koefisien Error }\end{array}$




\section{HASIL DAN PEMBAHASAN \\ Statistik Deskriptif}

Hasil statistik deskriptif berdasarkan data olahan SPSS yang meliputi: tax avoidance, ukuran perusahaan dan dewan komisaris independen adalah sebagai berikut:

\section{Tabel 2}

Hasil Analisis Deskriptif

\begin{tabular}{|c|c|c|c|c|c|}
\hline & $\mathrm{N}$ & Minimum & Maximum & Mean & Std. Deviation \\
\hline Tax Avoidance & 255 & .00 & 165.37 & 31.7405 & 21.59686 \\
\hline Ukuran Perusahaan & 255 & 25.94 & 32.47 & 29.0913 & 1.59572 \\
\hline $\begin{array}{ll}\text { Dewan } & \text { Komisaris } \\
\text { Independen } & \end{array}$ & 255 & .00 & 66.67 & 38.9862 & 10.80997 \\
\hline Transfer Pricing & 255 & 0 & 1 & .71 & 457 \\
\hline Valid N (listwise) & 255 & & & & \\
\hline
\end{tabular}

Berdasarkan tabel 2 di atas dapat diketahui bahwa $\mathrm{N}$ atau jumlah data setiap variabel yang valid berjumlah 255. Transfer pricing (Y) yang diukur dengan melihat ada atau tidaknya transaksi penjualan kepada pihak berelasi pada catatan atas laporan keuangan bagian transaksi penjualan pihak berelasi. Transfer pricing (Y) memiliki nilai minimum sebesar 0, nilai maksimum sebesar 1, nilai mean dari periode 2017-2019 sebesar 0,71 yang berarti 71\% dari $100 \%$ perusahaan melakukan transfer pricing dan nilai standar deviasi sebesar 0,457 , sehingga dapat disimpulakan nilai mean lebih besar dari nilai standar deviasi. Hal ini berarti bahwa penyimpangan data yang terjadi rendah maka penyebaran nilai merata.

Tax avoidance (X1) yang diukur dengan cara melihat laporan laba rugi perusahaan yaitu bagian beban pajak dan laba sebelum pajak. Hasil dari analisis deskriptif dapat disimpulkan bahwa dari 255 sampel diketahui nilai minimum sebesar 0, nilai maksimum sebesar 165,37, nilai mean dari periode 2017-2019 sebesar 31,7405 dan nilai standar deviasi sebesar 21,59686, sehingga nilai mean lebih besar dari nilai standar deviasi yang berarti bahwa penyimpangan data yang terjadi rendah maka penyebaran nilai merata.

Ukuran perusahaan (X2) diukur dengan logaritma natural (LN) total aset perusahaan yang didapatkan dari laporan posisi keuangan perusahaan. Hasil dari analisis deskriptif dapat disimpulkan bahwa 255 sampel diketahui nilai minimum sebesar 25,94, nilai maksimum sebesar 32,47, nilai mean dari periode 2017-2019 sebesar 29,0913 dan nilai standar deviasi sebesar 1,59572, sehingga nilai mean lebih besar dari nilai standar deviasi yang berarti bahwa penyimpangan data yang terjadi rendah maka penyebaran nilai merata.

Dewan komisaris independen (X3) diukur dengan cara membandingkan jumlah dewan komisaris independen dengan jumlah dewan komisaris yang bisa dilihat dari laporan tahunan pada bagian dewan komisaris. Hasil analisis deskriptif dapat disimpulkan bahwa dari 255 sampel diketahui nilai minimum sebesar 0,00, nilai maksimum sebesar 66,67, nilai mean dari periode 2017-2019 sebesar 38,9862, dan nilai standar deviasi sebesar 10,80997, sehingga nilai mean lebih besar dari nilai standar deviasi yang berarti bahwa penyimpangan data yang terjadi rendah maka penyebaran nilai merata.

\section{Hasil Analisis Regresi \\ Uji Kelayakan Model}

Tabel 3

Hasil Hosmer and Lemeshow Test

\begin{tabular}{cccc}
\hline Step & Chi-square & Df & Sig. \\
\hline 1 & 12.146 & 8 & .145 \\
\hline
\end{tabular}


Pada tabel 3 didapatkan nilai signifikansi dari hasil pengujian yaitu sebesar 0,145> 0,05 hal tersebut menunjukkan bahwa tidak ada perbedaan antara model dengan data. Data tersebut memiliki kesimpulan bahwa data tepat dan cocok dalam menguji hipotesis dan tidak ada perbedaan yang signifikan antara klasifikasi yang diprediksi dengan yang diamati sehingga analisis selanjutnya dapat dilakukan.

\section{Uji Akurasi Model}

Tabel 4

Hasil Uji Akurasi Model

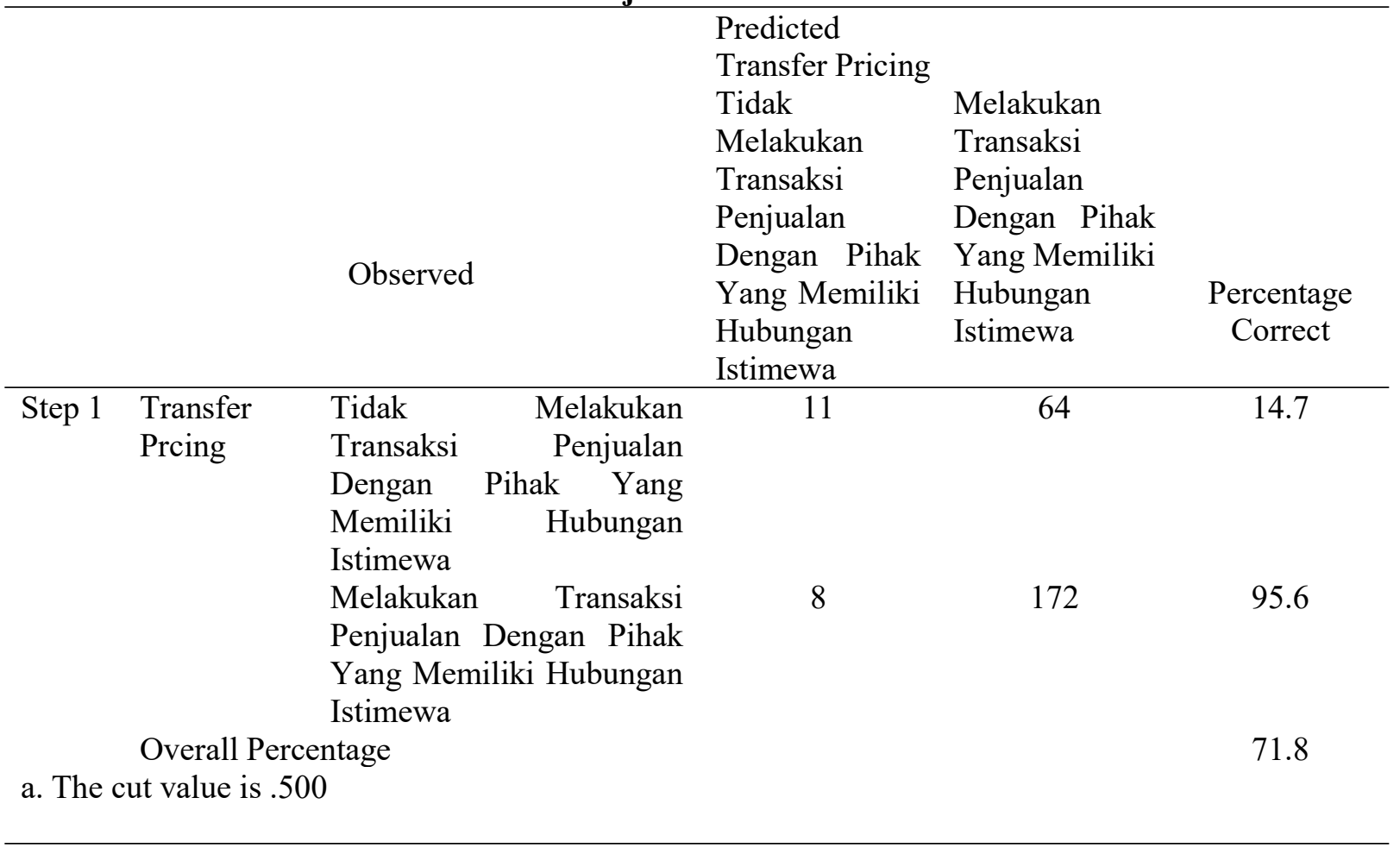

Berdasarkan tabel 4 dapat dilihat secara keseluruhan, model ini mampu memprediksi secara tepat sebesar $71,8 \%$ dari seluruh data yang ada, maka $28,2 \%$ lainnya memiliki kemungkinan model yang tidak dapat memprediksi hasil secara tepat. Hasil uji akurasi ini dikatakan cukup baik dan akurat dalam memprediksi hasil.

\section{Uji Keseluruhan Model}

Tabel 5

Hasil Uji Keseluruhan Model (Overall Model Fit)

-2LL awal (Block Number $=0$ ) 309.101

-2LL awal (Block Number $=1)$

289.192

Dari hasil tabel 5 di atas diketahui bahwa nilai -2LL awal sebesar 309,101 dan nilai 2LL akhir sebesar 289,192 yang berarti mengalami penurunan. Penurunan ini menunjukkan model regresi yang baik atau dengan kata lain model yang dihipotesiskan fit dengan data, artinya penambahan variabel tax avoidance, ukuran perusahaan dan dewan komisaris independen akan memperbaiki model fit penelitian ini. 
Analisis Regresi Logistik

Tabel 6

Hasil Model Regresi

\begin{tabular}{|c|c|c|c|c|c|c|c|}
\hline & & B & S.E. & Wald & $\mathrm{df}$ & Sig. & $\operatorname{Exp}(\mathrm{B})$ \\
\hline \multirow[t]{4}{*}{ Step $1^{\mathrm{a}}$} & $\mathrm{X} 1$ & -.010 & .007 & 2.134 & 1 & .144 & .990 \\
\hline & $\mathrm{X} 2$ & .435 & 101 & 18.586 & 1 & .000 & 1.545 \\
\hline & X3 & -.013 & .013 & 1.030 & 1 & .310 & .987 \\
\hline & Constant & -10.870 & 2.821 & 14.844 & 1 & .000 & .000 \\
\hline
\end{tabular}

Hasil pengujian terhadap koefisien regresi logistik menghasilkan model sebagai berikut :

$$
\mathrm{TP}=-10,870-0,010 \mathrm{X} 1+0,435 \mathrm{X} 2-0,013 \mathrm{X} 3+\varepsilon
$$

Nilai taksiran yang terdapat pada persamaan regresi logistik dapat diinterpretasikan dari nilai $B$ atau odds ratio diperoleh sebagai berikut: Nilai konstanta $(\alpha)$ sebesar $-10,870$ menunjukkan bahwa apabila variabel tax avoidance (X1), ukuran perusahaan (X2), dan dewan komisaris independen (X3) dianggap konstan, maka keputusan melakukan transfer pricing $(\mathrm{Y})$ yang dilakukan perusahaan menurunan sebesar $1870 \%$. Nilai koefisien regresi dari tax avoidance (X1) sebesar -0,010 yang bertanda negatif. Hal ini menunjukkan bahwa setiap kenaikan tax avoidance (X1), maka keputusan melakukan transfer pricing (Y) akan mengalami penurunan sebesar 1\%. Nilai koefisien regresi ukuran perusahaan (X2) menghasilkan nilai sebesar 0,435 yang bertanda positif. Hal ini menunjukkan bahwa setiap kenaikan ukuran perusahaan (X2), maka keputusan melakukan transfer pricing (Y) akan meningkat sebesar sebesar 43,5\%. Nilai koefisien regresi dewan komisaris independen (X3) menghasilkan nilai sebesar $-0,013$ yang bertanda negatif. Hal ini menunjukkan bahwa setiap kenaikan dewan komisaris independen (X3), maka keputusan melakukan transfer pricing (Y) akan mengalami penurunan sebesar $1,3 \%$.

\section{Pengujian Hipotesis}

Uji T

Tabel 7

Hasil Uji T

\begin{tabular}{|c|c|c|c|c|c|c|c|}
\hline & & B & S.E. & Wald & Df & Sig. & $\operatorname{Exp}(\mathrm{B})$ \\
\hline \multirow{4}{*}{ Step $1^{\mathrm{a}}$} & $\mathrm{X} 1$ & -.010 & .007 & 2.134 & 1 & .144 & .990 \\
\hline & $\mathrm{X} 2$ & .435 & .101 & 18.586 & 1 & .000 & 1.545 \\
\hline & X3 & -.013 & .013 & 1.030 & 1 & .310 & 987 \\
\hline & Constant & -10.870 & 2.821 & 14.844 & 1 & .000 & .000 \\
\hline
\end{tabular}

a. Variable(s) entered on step 1: X1, X2, X3.

\section{Pengujian Hipotesis Pertama ( H1)}

Pada variabel tax avoidance (X1) diperoleh tingkat signifikansi ( $\rho$-value) sebesar $0,144>$ 0,05 . Karena tingkat signifikan lebih besar dari $\alpha=0,05$ maka variabel tax avoidance tidak berpengaruh terhadap transfer pricing, maka hipotesis pertama bahwa tax avoidance berpengaruh positif terhadap transfer pricing ditolak.

\section{Pengujian Hipotesis Kedua (H2)}

Pada variabel ukuran perusahaan (X2) tingkat signifikansi ( $\rho$-value) sebesar $0,000<0,05$. Karena tingkat signifikan lebih kecil dari $\alpha=0,05$ maka variabel ukuran perusahaan berpengaruh terhadap transfer pricing dan nilai dari B ukuran perusahaan diperoleh sebesar 0,435 bertanda negatif $(+)$ maka hipotesis ke-2 yang menyatakan bahwa ukuran perusahaan berpengaruh positif terhadap transfer pricing diterima.

Pengujian Hipotesis ketiga (H3) 
Pada variabel dewan komisaris independen (X3) diperoleh tingkat signifikansi ( $\rho$ value) sebesar $0,310>0,05$. Karena tingkat signifikan lebih besar dari $\alpha=0,05$ maka variabel dewan komisaris independen tidak berpengaruh terhadap transfer pricing maka hipotesis ke-3 bahwa dewan komisaris independen berpengaruh positif terhadap transfer pricing ditolak.

\section{Koefisien Determinasi (Nagelkerke R Square)}

\section{Tabel 8}

Nilai Nagelkerke R Square

\begin{tabular}{lrrr}
\hline Step & -2 Log likelihood & Cox \& Snell R Square & Nagelkerke R Square \\
\hline 1 & $287.473^{\mathrm{a}}$ & .081 & .115 \\
\hline
\end{tabular}

a. Estimation terminated at iteration number 5 because parameter estimates changed by less than .001 .

Pada tabel 8 menunjukkan bahwa nilai Nagelkerke R Square sebesar 0,115 yang berarti variabilitas variabel dependen yang dapat dijelaskan oleh variabel independen sebesar $11,5 \%$, sisanya sebesar $88,5 \%$ dijelaskan oleh variabel-variabel lain diluar model penelitian.

\section{PEMBAHASAN}

\section{Pengaruh Tax Avoidance terhadap Transfer Pricing}

Hipotesis pertama dalam penelitian ini adalah tax avoidance berpengaruh positif terhadap transfer pricing. Berdasarkan hasil pengujian pada tabel 7 untuk variabel tax avoidance memiliki signifikansi sebesar $0,144>0,05$ yang berarti tax avoidance yang diukur dengan effective tax rate tidak berpengaruh terhadap transfer pricing sehingga hipotesis pertama dalam penelitian ini ditolak. Hasil penelitian ini tidak konsisten dengan hasil Rosad et al. (2020) bahwa penghindaran pajak mempunyai pengaruh positif signifikan terhadap transfer pricing. Namun hasil penelitian ini konsisten dengan penelitian yang dilakukan oleh Arifin et al. (2020) yang mendapatkan hasil bahwa pajak tidak berpengaruh signifikan terhadap transfer pricing. Sejalan dengan penelitian Arifin et al. (2020), Hadifadhlulloh (2020) juga mendapatkan hasil penelitian bahwa tax avoidance tidak berpengaruh terhadap transfer pricing.

Berdasarkan tax avoidance yang di ukur dengan effective tax rate, apabila nilai ETR semakin kecil berarti penghindaran pajak oleh perusahaan semakin besar dan begitu pula sebaliknya, nilai ETR yang semakin besar maka penghindaran pajaknya semakin kecil. Pada penelitian ini tax avoidance mendapatkan nilai mean 31,7405, dengan nilai minumum 0 dan nilai maksimum 165,37. Hal tersebut berarti perusahaan melakukan penghindaran pajak kecil, dimana nilai tax avoidance diatas angka 100 mengindikasikan bahwa perusahaan tidak melakukan tax avoidance. Menurut Khotimah (2019), tingginya beban pajak tidak mempengaruhi perusahaan melakukan transfer pricing karena semakin ketatnya pengawasan dari petugas pajak atau fiskus terhadap perusahaan menyebabkan perusahaan akan berhatihati dalam melakukan keputusan transfer pricing.

Dalam Peraturan Dirjen Pajak No.PER-42/PJ/2011 membahas mengenai implementasi prinsip kewajaran dan kelaziman usaha berkaitan dengan transaksi antara wajib pajak dengan pihak afiliasi. Dalam prinsip kewajaran dan kelaziman usaha, harga transfer sebaiknya ditetapkan agar mencerminkan harga yang disepakati walaupun transaksi tersebut dilakukan oleh pihak yang tidak mempunyai hubungan istimewa. Tujuan utama dari kebijakan perusahaan dalam melakukan transfer pricing adalah untuk mengevaluasi dan mengukur kinerja perusahaan. Transfer pricing yang dilakukan berdasarkan harga pasar tidak akan berdampak pada perpajakan. Oleh karena itu, transfer pricing tidak selalu dikonotasikan 
menjadi arti yang kurang baik saja, namun juga dapat dilihat dari tujuan perusahaan untuk melakukan transfer pricing.

Menteri keuangan menerbitkan peraturan nomor 22/PMK.03/2020 (PMK 22) mengenai tata cara pembentukan dan pelaksanaan kesepakatan harga transfer/Advance Pricing Agreement (APA). Peraturan ini bertujuan agar para wajib pajak mematuhi persyaratan penentuan harga transfer dan memberikan indikasi bahwa kemungkinan kesepakatan yang dibuat berdasarkan APA tidak boleh merugikan Indonesia dari sisi pajak (Deloitte, 2020).

\section{Pengaruh Ukuran Perusahaan terhadap Transfer Pricing}

Hipotesis kedua dalam penelitian ini adalah ukuran perusahaan berpengaruh positif terhadap transfer Pricing. Berdasarkan hasil pengujian pada tabel 7 , variabel ukuran perusahaan memiliki signifikansi $0,000<0,05$ dengan koefisien sebesar 0,435 . Hal ini berarti bahwa ukuran perusahaan berpengaruh positif terhadap transfer pricing pada perusahaan sektor pertanian, sektor pertambangan dan sektor industri dasar dan kimia yang terdaftar di Bursa Efek Indonesia (BEI) tahun 2017-2019, sehingga hipotesis kedua dalam penelitian ini diterima. Hasil penelitian ini konsisten dengan hasil penelitian yang dilakukan oleh Pratama et al (2020) bahwa ukuran perusahaan secara signifikan terkait positif dengan transfer pricing, hasil yang sama juga ditemukan oleh, Rezky \& Fachrizal (2018), Saputra (2020) dan Sulistyowati \& Kananto (2018) bahwa ukuran perusahaan secara positif mempengaruhi transfer pricing.

Ukuran perusahaan menunjukkan peran perusahaan dalam mengelola aset perusahaan dalam rangka mencapai tujuan perusahaan. Aset perusahaan diharapkan dapat dikelola dengan baik maka dari itu perlu adanya kebijakan dan arah strategi perusahaan, baik untuk jangka pendek maupun jangka panjang serta mengevaluasi kebijakan manajemen dan pemecahan masalah yang sedang dihadapi perusahaan. Hal ini disebabkan karena perusahaan besar memiliki peluang besar dalam melakukan praktik transfer pricing dengan skala besar.

Hasil penelitian tersebut mengindikasikan bahwa semakin besarnya ukuran perusahaan akan mempermudah perusahaan untuk melakukan transfer pricing antar perusahaan karena semakin banyak sumberdaya yang dimiliki, sehingga perusahaan dapat mendirikan anak perusahaan di berbagai negara yang dapat menguntungkan perusahaan. Perusahaan yang memiliki ukuran yang besar akan lebih banyak mendapatkan perhatian publik, sehingga perusahaan akan berusaha meningkatkan laba untuk menarik perhatian investor.

\section{Pengaruh Dewan Komisaris Independen Terhadap Transfer Pricing}

Hipotesis ketiga dalam penelitian ini yaitu dewan komisaris independen berpengaruh positif terhadap Transfer Pricing. Berdasarkan pengujian pada tabel 7, variabel dewan komisaris independen memiliki signifikansi $0,310>0,05$ yang berarti dewan komisaris independen tidak berpengaruh terhadap transfer pricing pada perusahaan sektor pertanian, sektor pertambangan dan sektor industri dasar dan kimia yang terdaftar di Bursa Efek Indonesia (BEI) tahun 2017-2019, sehingga hipotesis ketiga dalam penelitian ini ditolak. Hal tersebut berarti bahwa good corporate governance yang diukur melalui keberadaan dewan komisaris independen tidak mempengaruhi kebijakan perusahaan dalam melakukan transfer pricing.

Pada penelitian ini didapatkan hasil bahwa komisaris independen tidak berpengaruh terhadap transfer pricing, hasil penelitian ini sejalan dengan hasil penelitian yang dilakukan oleh Noviastika F. et al. (2016) bahwa good corporate governance tidak berpengaruh terhadap transfer pricing. Proporsi komisaris independen yang ditetapkan oleh Otoritas Jasa Keuangan yaitu sebesar $30 \%$, sehingga tidak dapat mengimbangi pengambilan keputusan. 
Menurut Lorsch (2000) jumlah dewan komisaris independen dalam perusahaan harus diatas $50 \%$ supaya dapat mengimbangi suara dewan komisaris yang berada di dalam perusahaan. Kebanyakan dari dewan komisaris independen bukan ahli akuntansi dan keuangan, sehingga tidak dapat mempengaruhi kebijakan transfer pricing.

Menurut Moenaf (2000) dewan komisaris harus terdiri dari berbagai bidang dan diantaranya harus ada ahli akuntansi dan keuangan, karena fungsi kunci dewan komisaris diantaranya adalah meyakini integritas akuntansi dan sistem pelaporan keuangan korporasi (OECD, 2004). Komisaris independen bekerja tidak profesional karena diangkat berdasarkan atas kedekatan hubungan dengan manajemen dan atau pemegang saham mayoritas (Herwidayatmo dalam FCGI, 2001). Menurut Moenef (2000) sebaiknya komisaris independen harus memiliki kompetensi, pengetahuan dan kemampuan memadai serta pemahaman masalah bisnis, keuangan dan akuntansi agar dapat mendeteksi transaksitransaksi yang ada dalam perusahaan.

\section{SIMPULAN DAN KETERBATASAN Simpulan}

Berdasarkan hasil penelitian yang telah dilakukan peneliti pada 85 perusahaan sektor pertanian, sektor pertambangan dan sektor industri dasar dan kimia yang terdaftar di Bursa Efek Indonesia (BEI) periode 2017-2019 dengan total sampel 255 dapat disimpulkan sebagai berikut:

1. Hasil penelitian menunjukkan bahwa tax avoidance tidak berpengaruh terhadap keputusan transfer pricing.

2. Hasil penelitian menunjukkan bahwa ukuran perusahaan berpengaruh positif terhadap transfer pricing.

3. Hasil penelitian menunjukkan bahwa dewan komisaris independen tidak berpengaruh terhadap transfer pricing.

\section{Keterbatasan}

Pada penelitian ini terdapat beberapa keterbatasan, yaitu:

1. Periode atau tahun penelitian ini 3 tahun (2017-2019) karena pada tahun sebelumnya banyak perusahaan mengalami kerugian sehingga jika ditambahkan tahun sebelumnya dapat mengurangi sampel penelitian. Penelitian selanjutnya sebaiknya memperluas periode atau tahun penelitian dengan memilih sektor lainnya sehingga sampel penelitian lebih banyak

2. Hasil dari koefisien determinasi pada penelitian ini yaitu $11,5 \%$ hal tersebut berarti masih banyaknya variabel lainnya yang mempengaruhi transfer pricing. sehingga untuk peneliti selanjutnya dapat menambahkan variabel lainnya, seperti mekanisme bonus, tunneling incentive dan lainnya.

3. Transfer pricing pada penelitian ini diukur dengan melihat transaksi penjualan kepada pihak yang memiliki hubungan istimewa. Penelitian selanjutnya sebaiknya dapat menggunakan proksi transfer pricing lain.

\section{DAFRTAR PUSTAKA}

Andayani, Arum Sasi, and Ardiani Ika Sulistyawati. 2020. "Pengaruh Pajak, Tunneling Incentive Dan Good Corporate Governance (Gcg) Dan Makanisme Bonus Terhadap Indikasi Transfer Pricing Pada Perusahaan Manufaktur." Majalah Ilmiah Solusi 18(1):33-50. doi: http://dx.doi.org/10.26623/slsi.v18i1.2099.

Arham, Amardianto, Amrie Firmansyah, and Aji M. Elvin Nor. 2020. "Penelitian Transfer Pricing Di Indonesia: Sebuah Studi Kepustakaan." Jurnal Online Insan Akuntan 5(June):57-72. doi: 10.51211/joia.v5i1.1318. 
Asyhinta, P.J., Agustin, Henri, Afriyenti, Mayar. (2019). Pengaruh Tunneling Incentive, Mekanisme Bonus Dan Exchange Rate Terhadap Keputusan Perusahaan Melakukan Transfer Pricing (Studi Pada Perusahaan Manufaktur Yang Terdaftar di Bursa Efek Indonesia Tahun 2014-2017). Jurnal Eksplorasi Akuntansi, 1(2), Seri A, 572-588

Arifin, Atwal, Africo Al-dua Saputra, and Heppy Purbasari. 2020. "Company Size, Profitability, Tax , and Good Corporate Governance on the Company' s Decision to Transfer Pricing." Riset Akuntansi Dan Keuangan Indonesia 5(1):141-50.

Darussalam, D. Danny Septiriadi, and B. Bawono Kristiaji. 2013. Transfer Pricing Ide, Strategi, Dan Panduan Praktis Dalam Perspektif Pajak International. Jakarta: anny Darussalam Tax Center (PT Dimensi International Tax).

Deloitte. 2020. "Indonesia Transfer Pricing Alert." Deloitte Touche Solutions, 1-5.

Dyreng, Scott D., Michelle Hanlon, and Edward L. Maydew. 2008. "Long-Run Corporate Tax Avoidance." The Accounting Review 83(1):61-82

Fama, Eugena F., and Michael C. Jensen. 1983. "Separation of Ownership and Control." Journal of Law and Economic 26(2):32.

Fuest, Clemens, Shafik Hebous, and Nadine Riedel. 2011. International Profit Shifting and Multinational Firms in Developing Countries.

Jafri, Hasan Effendi, and Elia Mustikasari. 2018. "Pengaruh Perencanaan Pajak, Tunneling Incentive Dan Aset Tidak Berwujud Terhadap Perilaku Transfer Pricing." Berkala Akuntansi Dan Keuangan Indonesia 03(02):63-77.

Jensen, Michael C., and William H. Meckling. 1976. "Theory of the Firm: Managerial Behavior, Agency Costs and Ownership Structure." Journal of Financial Economics 3:305-60. doi: 10.1177/0018726718812602.

Karunia, Putu Agus Ray. 2020. "Ini Dia Transfer Pricing Penghambat Kenaikan Rasio Pajak." Https://Www.Pajak.Go.Id. Retrieved February 27, 2021 (https://www.pajak.go.id/id/artikel/ini-dia-transfer-pricing-penghambat-kenaikanrasio-pajak).

Marfuah, and Andri Puren Noor Azizah. 2014. "Pengaruh Pajak, Tunneling Incentive Dan Exchange Rate Pada Keputusan Transfer Pricing Perusahaan." JAAI 18 No. 2(Desember):156-65.

Noviastika F., Dwi, Yuniadi Mayowan, and Suhartini Karjo. 2016. "Pengaruh Pajak, Tunneling Incentive Dan Good Corporate Governance (GCG) Terhadap Indikasi Melakukan Transfer Pricing." Jurnal Perpajakan (JEJAK) 8(1):1-9.

Novriansa, Azim. 2019. "Sektor Pertambangan Rawan Manipulasi Transfer Pricing?" News.Ddtc.Co.Id. Retrieved February 26, 2021 (https://news.ddtc.co.id/sektorpertambangan-rawan-manipulasi-transfer-pricing-17422?page_y $=0$ ).

Park, Sung Jin, Woo Jin Park, Eun Jung Sun, and Sohee Woo. 2016. "Is Foreign Direct Investment Effective from the Perspective Of Tax Avoidance? An Analysis Of Tax Tvoidance through the International Transfer Pricing Behaviors of Korean Corporations." The Journal of Applied Business Research 32(3):917-34. doi: https://doi.org/10.19030/jabr.v32i3.9664.

Pratama, Arie. 2020. "Corporate Governance , Foreign Operations and Transfer Pricing Practice: The Case of Indonesian Manufacturing Companies." J. Business and Globalisation 24(2). doi: 10.1504/IJBG.2020.105167.

Rezky, Machfirah Aprilia, and Fachrizal Fachrizal. 2018. "Pengaruh Makanisme Bonus, Ukuran Perusahaan, Leverege Dan Multinationality Terhadap Keputusan Transfer Pricing." Jurnal Ilmiah Mahasiswa Ekonomi AkuntasI (JIMEKA) 3(3):401-15.

Richardson, Grant, Grantley Taylor, and Roman Lanis. 2013. "Determinants of Transfer Pricing Aggressiveness: Empirical Evidence from Australian Firms." Journal of Contemporary Accounting and Economics 9(2):136-50. doi: 
10.1016/j.jcae.2013.06.002.

Rosad, Dede Abdul, Erik Nugraha, and Rizki Fajri. 2020. "Faktor-Faktor Yang Mempengaruhi Keputusan Untuk Melakukan Transfer Pricing." Jurnal Akuntansi Netral, Akuntabel, Objektif 2:293-305.

Saputra, Africo Al-dua. 2020. "Pengaruh Ukuran Perusahaan, Profitabilitas, Pajak Dan Kualitas KAP Terhadap Keputusan Perusahaan Melakukan Transfer Pricing."

Saraswati, Gusti Ayu Rai Surya, and I. Ketut Sujana. 2017. "Pengaruh Pajak, Mekanisme Bonus Dan Tunneling Incentive Pada Indikasi Melakukan Transfer Pricing." E-Jurnal Akuntasi Universitas Udayana 19.2(Mei):1000-1029.

Sulistyowati, Sulistyowati, and R. Kananto. 2018. "The Influences of Tax , Bonus Mechanism , Leverage and Company Size through Company Decision on Transfer Pricing." Pp. 207-12 in Advance in Economics, Business and Management Research. Vol. 73.

Susilo, Richard. 2017. "Indonesia Masuk Peringkat Ke-11 Penghindaran Pajak Perusahaan, Jepang No.3." Tribunnews.Com. Retrieved (https://www.tribunnews.com/internasional/2017/11/20/indonesia-masuk-peringkatke-11-penghindaran-pajak-perusahaan-jepang-no3).

Suwiknyo, Edi. 2019. "OECD : Kasus Transfer Pricing Meningkat." Ekonomi.Bisnis.Com. Retrieved (https://ekonomi.bisnis.com/read/20190918/259/1149724/oecd-kasustransfer-pricing-meningkat).

Wareza, Monica. 2019. "Disebut Terlibat Transfer Pricing Adaro, Siapa Coaltrade?" Cnbcindonesia.Com.(https: //www.cnbcindonesia.com/news /20190704205102-482830/disebut-terlibat-transfer-pricing-adaro-siapa-coaltrade).

Yuniasih, N. .., K. Rasmini, and G. Warakusuma M. 2012. "Pengaruh Pajak, Dan Tunneling Incentive Pada Keputusan Transfer Pricing Perusahaan Manufaktur Di Bursa Efek Indonesia." SNA XV Banjarmasin (September):20-23. 